\title{
Vitamin D Deficiency and Rheumatoid Arthritis
}

\author{
Larissa Lumi Watanabe Ishikawa $^{1} \cdot$ Priscila Maria Colavite $^{1} \cdot$ \\ Thais Fernanda de Campos Fraga-Silva ${ }^{1}$ - Luiza Ayumi Nishiyama Mimura ${ }^{1}$. \\ Thais Graziela Donegá França ${ }^{1} \cdot$ Sofia Fernanda Gonçalves Zorzella-Pezavento ${ }^{1}$ • \\ Fernanda Chiuso-Minicucci ${ }^{1} \cdot$ Larissa Doddi Marcolino $^{2} \cdot$ Marcimara Penitenti $^{3}$. \\ Maura Rosane Valerio Ikoma ${ }^{3} \cdot$ Alexandrina Sartori $^{1}$
}

Published online: 2 August 2016

(C) Springer Science+Business Media New York 2016

\begin{abstract}
Vitamin D (VitD) is a hormone primarily synthesized in human skin under the stimulation of ultraviolet radiation. Beyond its endocrine role in bone metabolism, VitD is endowed with remarkable immunomodulatory properties. The effects of VitD on the immune system include the enhancement of microbicidal ability of monocytes/ macrophages and the down-modulation of inflammatory cytokines produced by $\mathrm{T}$ lymphocytes. VitD deficiency is involved in many health problems, including immune-mediated diseases such as autoimmune disorders. Rheumatoid arthritis (RA) is a chronic inflammatory systemic autoimmune disease that compromises the joints, causing cartilage destruction and bone erosion. RA treatment usually consists of combined therapies that generally suppress the entire immune response leading to increased susceptibility to infections. This review describes the main effects of VitD on innate and adaptive immune system and also VitD status in inflammatory rheumatic diseases such as RA. Despite some controversies, the majority of reports reinforce the idea that lower VitD levels correlate with more severe clinical manifestations in RA and
\end{abstract}

Electronic supplementary material The online version of this article (doi:10.1007/s12016-016-8577-0) contains supplementary material, which is available to authorized users.

Larissa Lumi Watanabe Ishikawa

larissalumi@gmail.com

1 Department of Microbiology and Immunology, Institute of Biosciences of Botucatu, São Paulo State University (UNESP), Botucatu, São Paulo, Brazil

2 Department of Pathology, Botucatu Medical School, Botucatu, São Paulo, Brazil

3 Flow Cytometry Laboratory, Amaral Carvalho Foundation, Jaú, São Paulo, Brazil other rheumatic diseases. Therefore, supplementation with VitD to achieve normal serum levels is worthwhile as an aforethought. Original data concerning the potential applicability of 1,25-dihydroxyvitamin $\mathrm{D}_{3}$ (VitD3), the active form of vitamin $\mathrm{D}$, as a tolerogenic adjuvant are also included. In this sense, the effect of VitD3 associated with proteoglycan (PG), which is a specific cartilage antigen, was tested in the course of experimental arthritis. This association significantly lowered clinical scores and local histopathological alterations. Even though local analysis of $\mathrm{T}$ cell subsets and cytokine production did not reveal any difference between the experimental groups, VitD3+PG association significantly reduced cytokine production by spleen cells. These results suggest that VitD3 played a role as a tolerogenic adjuvant by downmodulating the course of experimental RA. Considering this tolerogenic effect of VitD3+PG association, further investigations will reveal its plausible use in human RA.

Keywords Vitamin D · Immunomodulation · Rheumatoid arthritis · Experimental arthritis · Proteoglycan · Tolerance

\section{Introduction}

Vitamin D (VitD) can be found in foods such as mushrooms, fish, milk, and eggs [1]; however, only around $5 \%$ of total VitD is provided by food ingestion [2]. The primary source of VitD is 7-dehydrocholesterol, which is present in large amounts in human skin. Ultraviolet (UV) B radiation from sunlight converts cutaneous 7-dehydrocholesterol into previtamin D3, which turns into cholecalciferol via thermal isomerization [3]. To become metabolically active, cholecalciferol is first converted into 25-dihydroxyvitamin $\mathrm{D}_{2}$ (calcidiol) by the enzyme 25-hydroxylase in the liver [4]. Then, it is transported to tissues that express the enzyme $1 \alpha$ - 
hydroxylase (CYP27B1) [5], mainly to the kidneys, where a second hydroxylation occurs and generates the bioactive metabolite 1,25-dihydroxyvitamin $\mathrm{D}_{3}$ (VitD3), also known as calcitriol [6]. Due to its short half-life, VitD3 may not be precisely measured in the organism. Thus, serum levels of the precursor calcidiol are used to determine the overall VitD status. Although there is no consensus about the serum VitD levels in healthy and pathological conditions, around 30 to $100 \mathrm{ng} / \mathrm{mL}$ is found in healthy individuals while concentrations between 21 and $29 \mathrm{ng} / \mathrm{mL}$ characterize a VitD insufficiency status. Levels below $20 \mathrm{ng} / \mathrm{mL}$ indicate a pronounced VitD deficiency $[7,8]$.

It is largely known that VitD3 plays a major role in bone metabolism as a steroid hormone [9]. However, the biological effects of calcitriol are beyond calcium and phosphorus homeostasis and its effects on both innate and adaptive immunity have been thoroughly studied. Calcitriol activity is mediated by the vitamin $\mathrm{D}$ receptor (VDR) which is a member of the nuclear hormone receptor superfamily. The biological effects of VitD3 can be elicited by both genomic and non-genomic mechanisms depending on the VDR location. The nongenomic mechanism is characterized by membrane VDR binding with direct effect of VitD3 on the cells, including, for example, the activation of protein kinase C [10]. Nevertheless, most of the immunomodulatory effects of VitD3 are elicited by the genomic mechanism. In this case, intracellular VDR heterodimerizes with retinoic X receptor after binding to VitD3 and then this complex is translocated to the nucleus to activate or inhibit a variety of genes [11]. VDR is found in many cell types including immune cells such as monocytes, macrophages, activated $\mathrm{T}$ and $\mathrm{B}$ lymphocytes, and dendritic cells (DCs) [12].

A growing body of evidence suggests that VitD deficiency could be involved in many health problems, including immune-mediated diseases such as autoimmune pathologies $[13,14]$. This review brings an overview of the immunomodulatory properties of VitD and its status in inflammatory rheumatic diseases. Some original data suggesting the potential applicability of VitD as a tolerogenic adjuvant are also described.

\section{Immunomodulatory Properties of Vitamin D: an Overview}

One of the most well-described effects of VitD3 in the innate immune system is the enhancement of the host's antimicrobial ability. Calcitriol induces the production of cathelicidins and defensins by monocytes and macrophages and also stimulates the production of IL- $1 \beta$, IL- 6 , IL- 8 , and TNF- $\alpha$ during infections $[15,16]$. Despite this stimulatory effect on the innate immunity, VitD3 generally down-modulates the adaptive immune responses. VitD3 is largely known to suppress $\mathrm{T}$ cell proliferation and also the production of IL- 2 and IFN- $\gamma[17$, 18]. A preferential inhibition of Th1 functions over Th2 cells by VitD3 was already a long-standing observation [19]. Besides, a shift from Th1 to Th2 response was also described [17]. However, the direct effects of VitD3 on Th2 cells are still conflicting. Boonstra et al. [20] observed an increased frequency of IL-4, IL-5, and IL-10-producing murine CD4+ T cells and a decreased frequency of IFN- $\gamma$-producing cells after in vitro stimulation with VitD3. On the other hand, StaevaVieira and Freedman [21] demonstrated that both IFN- $\gamma$ and IL-4 production by murine CD4+ T cells was inhibited after the in vitro addition of VitD3.

Calcitriol also acts upon Th17 cells, which constitute an important $\mathrm{T}$ cell subpopulation involved in the pathogenesis of many inflammatory conditions, including autoimmune diseases [22]. The in vitro addition of VitD3 in human $\mathrm{CD}^{+} \mathrm{T}$ cells cultures was able to inhibit the differentiation of Th17 cells and IL-17 production, even in Th17-polarizing conditions [23]. In experimental autoimmune uveitis, VitD3 suppressed autoimmune response through inhibition of Th17 activation, differentiation, and cytokine production [24]. Moreover, in experimental autoimmune encephalomyelitis (EAE), VitD3 inhibited Th17 cell differentiation and migration to the central nervous system (CNS) [25].

In vitro studies with human and murine cells indicate that DCs are highly modulated by VitD3. This hormone promotes alterations in DC phenotype and function by inhibiting their differentiation and maturation [26]. Human DCs differentiated in the presence of VitD3 presented reduced expression of maturation markers such as CD1a, MHCII, CD40, CD80, and CD86 [9]. It has been suggested that the decreased expression of these costimulatory molecules characterizes an immature or semi-mature state of DCs that determines a tolerogenic phenotype [27]. Besides, tolerogenic DCs induce the development of regulatory $\mathrm{T}$ cells (Tregs) which suppress inflammatory responses and are generally characterized by the expression of CD4 and CD25 molecules in their surface, the expression of intracellular Foxp3, and the production of anti-inflammatory cytokines such as IL-10 and TGF- $\beta$ [28]. Pena et al. [29] demonstrated that the co-culture of DCs pre-treated with VitD3 and $\mathrm{CD} 4^{+} \mathrm{CD} 25^{+} \mathrm{T}$ cells led to the induction of $\mathrm{CD} 4^{+} \mathrm{Foxp} 3^{+}$ Tregs. The main immunomodulatory properties of VitD3 are summarized in Fig. 1.

The beneficial role of VitD3 in autoimmune diseases has been supported by both experimental and clinical data. For example, treatment of adult NOD mice with calcitriol analog inhibited the production of IL-12 and IFN- $\gamma$ and prevented the infiltration of Th1 cells into the pancreas, blocking insulitis progression [30]. Serum levels of VitD3 are positively correlated with the frequency and function of Tregs in patients with multiple 
Fig. 1 An overview of the main immunomodulatory effects of active vitamin D

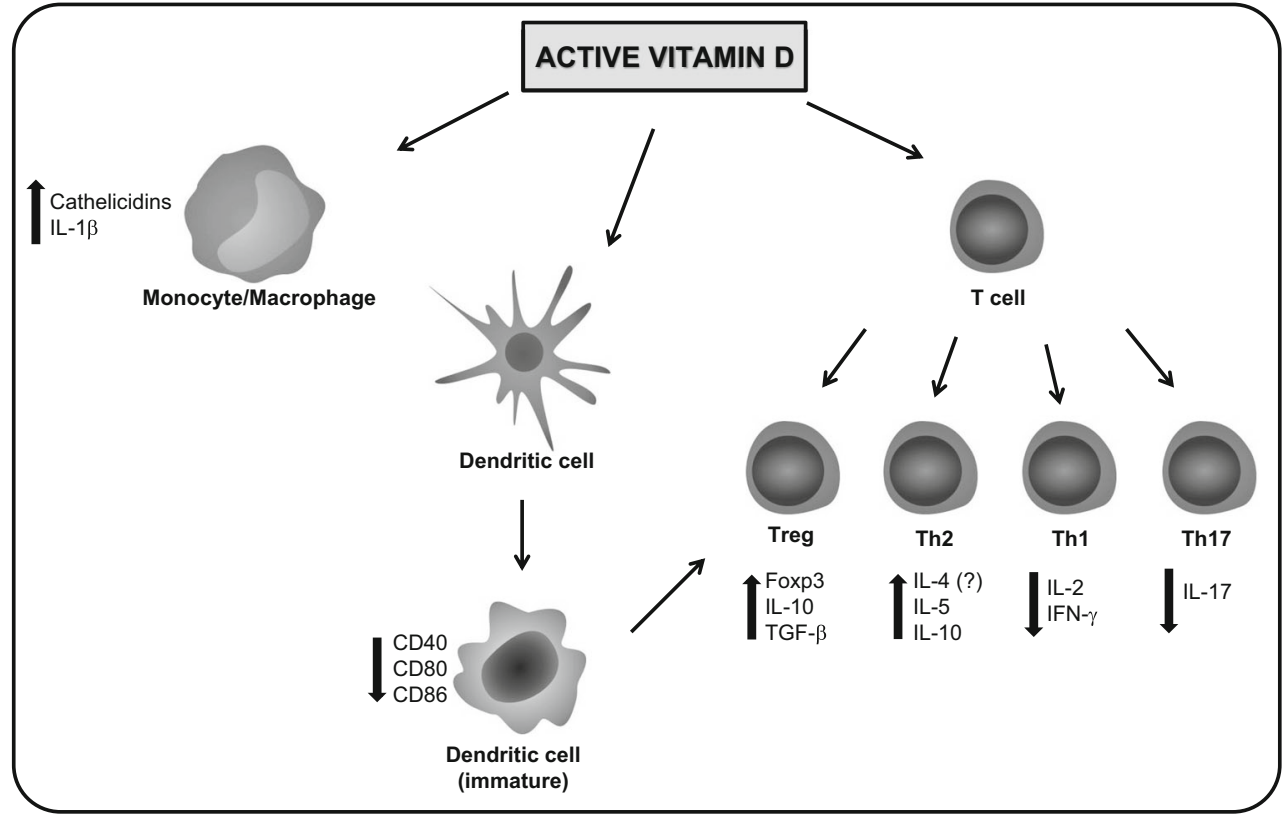

sclerosis [31]. In EAE, Spach et al. [32] demonstrated that the immunomodulatory effect of calcitriol was dependent upon a signaling pathway involving IL-10.

\section{Vitamin D Status in Inflammatory Rheumatic Disorders}

VitD status in health and disease is influenced by many factors such as geography and seasonal factors, age, body mass index, ethnicity, and drug interactions. Considering that sunlight exposure is essential for the maintenance of adequate VitD levels, latitude and seasonality are prominent variables [33]. A higher incidence of inflammatory autoimmune diseases, including rheumatoid arthritis (RA), for example, is observed in patients living in high latitudes where lower VitD levels are also detected [34]. These lower levels are also observed in other rheumatic diseases such as osteoarthritis, ankylosing spondylitis, undifferentiated connective tissue disease (UCTD), and psoriatic arthritis [35-38]. In UCTD, serum VitD levels were even more strikingly reduced during the winter than in the summer, showing that VitD status in this disease is also associated with seasonal factors. Regarding other inflammatory rheumatic diseases such as, for example, Behcet's disease and systemic sclerosis (SSc), a poor VitD status is usually associated with an increased disease risk and is also inversely correlated with disease activity [33, 39, 40]. Moreover, cutaneous fibrosis, which is an important SSc manifestation, was also negatively correlated with VitD concentration [41]. Despite this strong association between VitD status and disease activity, the role of hypovitaminosis D on the pathogenesis of SSc remains inconclusive [42].
Systemic lupus erythematosus (SLE) is one of the most challenging rheumatic disorders that is possibly influenced by VitD. Despite some contradictory findings, several studies have reported significantly lower serum VitD levels in SLE patients [43-45]. Recent data indicated that these lower levels were also associated with an increased risk for moderate to severe SLE manifestations in patients [46]. The association of VitD status with SLE activity, serological markers and disease risk related to VDR genes polymorphisms was recently reviewed by Watad et al. [47]. Regarding this, clinical trials evidenced the correlation between lower VitD levels and higher SLE activity [48, 49]. Additionally, a large prospective study including SLE patients supplemented with VitD suggested that proteinuria was also associated with VitD status [50]. The correlation between SLE risk/susceptibility and VDR polymorphisms is still controversial. However, Mao and Huang [51] performed a meta-analysis study and concluded that BsmI B allele, for example, may be associated with increased SLE susceptibility. Despite the relevance of VitD status in SLE, the management of VitD levels by sunlight exposure in SLE patients is not recommended because UV radiation contributes to disease pathogenesis. It has been suggested that, in genetically susceptible patients, UV radiation causes a dysregulation in the mechanism of apoptosis leading to the release of nuclear self-antigens [52]. Considering this, to avoid flares and cutaneous manifestation of the disease, SLE patients must protect themselves from the sunlight, which contributes to the lower serum VitD levels in these patients. Besides, Tabasi et al. [53] demonstrated that VitD is able to regulate cell cycle, apoptosis, and also the expression of apoptotic molecules in peripheral blood mononuclear cell cultures from SLE patients. In this sense, it is plausible to 
prescribe VitD supplementation in these patients even though there is no consensus concerning the amount that should be indicated. The current knowledge on VitD3 status and the putative beneficial role of VitD supplementation in autoimmune diseases, including SLE and other rheumatic disorders such as RA, was recently reviewed by Rosen et al. [54].

RA is the most common arthropathy affecting around $1 \%$ of the world population, with higher prevalence in women [55]. It is a disabling disease characterized by a chronic synovial inflammation that leads to joint destruction and consequent mobility impairment in more severe cases. Generally, like in all other autoimmune disorders, the etiology of RA involves a complex interplay between genetic and environmental factors [56]. VitD is considered one of the most relevant environmental factors affecting RA development. In this context, the association between serum VitD levels and the quality of life, physical performance, and disease activity in RA patients has been extensively evaluated. Raczkiewicz et al. [57] observed a mild to severe VitD deficiency in all RA patients that was inversely correlated with disease activity. Moreover, VitD status was positively correlated with the quality of life. A very recent meta-analysis study carefully reviewed the relevance of serum VitD levels in RA patients and concluded that low serum VitD levels are, indeed, inversely correlated with disease activity mainly in low-latitude and developing countries [58]. Likewise in the above-mentioned rheumatic disorders, VitD3 supplementation for RA patients is still being debated. Clinical data revealed some inconsistencies in the findings concerning VitD supplementation, mainly related to the concomitant conventional treatment. For example, VitD supplementation significantly reduced the pain in RA patients under treatment with combined diseasemodifying anti-rheumatic drugs (DMARDs) [59]. On the other hand, although there was no adverse effect, a high dose of VitD did not improve the clinical features in RA patients already receiving stable doses of methotrexate [60]. Additionally, in rheumatic diseases, especially in RA, the direct effect of VitD in bone metabolism must be considered. VitD3 supplementation is already indicated to prevent bone loss in some musculoskeletal diseases [61]. Rossini et al. [62] found a correlation between bone erosion and high levels of parathyroid hormone (PTH) in RA patients. These authors also suggested that VitD3 supplementation may be beneficial in RA by regulating PTH levels.

\section{Immunopathogenesis of RA and Its Control by Vitamin D}

The mechanisms underlying the immunopathogenesis of RA are not fully elucidated; however, it is known that components from both innate and adaptive immunity are involved [63]. The formation of pannus, which is a typical inflammatory tissue in RA, leads to synovial inflammation and consequently to the clinical manifestations of the disease. Together, pannus and synovitis comprise the main pathological features in RA [63]. Although mast cells, neutrophils, and natural killer cells may also have a role in RA synovitis, monocytes/ macrophages are the major effector cells of the innate immune system present in the synovial fluid and tissue. Once activated by cytokines, bacterial components, and/or hormones, macrophages produce inflammatory cytokines such as TNF- $\alpha$, IL$1 \beta$, and IL-6 which leads to synovitis [64]. Among other effects of TNF- $\alpha$ in RA, the induction of metalloproteinase (MMP) production and the inhibition of Treg differentiation in the joint are the most relevant [65]. IL- $1 \beta$ mediates articular damage and also induces the production of IL- 6 which is another important inflammatory cytokine in RA [66]. During the acute disease phase, IL-6 is present in elevated concentrations in the synovial fluid, which correlates with joint damage, especially concerning bone metabolism [67]. The relevance of TNF- $\alpha$ and IL- 6 in the pathogenesis of RA is evidenced by the currently available biological DMARD treatments that target these cytokines to ameliorate the disease symptoms [68]. Macrophages also interact with other infiltrating cell types such as fibroblasts and $\mathrm{T}$ and $\mathrm{B}$ cells, contributing to RA severity and chronicity [64].

Along with macrophages, DCs are in the interface between innate and adaptive immunity. Thus, these cells also play several roles in the pathogenesis of RA, including disease initiation and perpetuation. Regarding RA initiation, DCs are implicated in lymphocyte priming for self-antigens that occurs in autoimmune diseases [69]. Various self-antigens such as immunoglobulin G, collagen, fibrin, and fibrinogen and some post-translational modifications as citrullination are possibly involved in the immunopathogenesis of RA [70]. The selfantigen presentation by DCs induces the development of self-reactive $\mathrm{T}$ and $\mathrm{B}$ cells with consequent autoantibody production and cytokine release in joint and vascular tissues [71]. Inflammatory cytokines such as TNF- $\alpha$, IL-6, and IL-12 activate $\mathrm{DCs}$ via the NF-kB transcription factor pathway. Once activated, DCs are able to migrate to inflamed joints and infiltrate the synovial fluid and tissues through the expression of specific chemokine receptors. The continuous locally selfreactive events elicited by DCs in the synovium determine AR perpetuation [71].

Besides acting as antigen-presenting cells, B lymphocytes play a key role in the immunopathogenesis of RA through the production of autoantibodies and subsequent formation of immune complexes [72]. For many years, rheumatoid factor (RF), which binds to the Fc portion of $\mathrm{IgG}$, was considered the most important autoantibody in RA. Serum RF levels are still used for RA diagnosis; however, its correlation with arthritis severity is no longer a consensus [73]. Currently, the detection of anti-cyclic citrullinated peptides (anti-CCP) antibodies has been used as a complementary diagnostic criterion 
for AR [73]. Serum anti-CCP levels have been correlated with the expression of HLA-DR1 alleles which are involved in RA genetic risk. Thus, these antibodies could be detected even before disease onset [74].

The essential role of $\mathrm{T}$ cells in the immunopathogenesis of RA has been widely explored, and the involvement of Th1 cells mainly in the acute phase of the disease has been also reported $[75,76]$. The contribution of these cells to synovial inflammation and pannus formation is primarily mediated by the production of IFN- $\gamma$ [66]. Conversely, Th2 cells have a regulatory role in RA mediated by IL-4, inhibiting the production of TNF- $\alpha$, IL- 6 , and IFN- $\gamma$ and modulating osteoclastogenesis [66]. However, IL-4 synovial levels are low or even absent in RA patients, suggesting that the anti-inflammatory effects of this cytokine are impaired. A polymorphism in the IL-4 receptor that is observed in RA patients could explain the reduced responsiveness to IL-4 in these patients [77].

Th17 cells play a crucial role in the immunopathogenesis of RA. It is largely known that these cells present a functional plasticity regulated by the inflammatory cytokine milieu that determines their pathogenicity in autoimmune diseases including RA [78]. Th17 cells are characterized by the production of IL-17, a highly inflammatory cytokine that is also found in the synovium of RA patients [79]. The possible mechanisms by which IL-17 mediates synovial inflammation include the induction of pro-inflammatory cytokines, chemokines, and MMP production by macrophages, synovial fibroblasts, and chondrocytes. Additionally, IL-17 has a direct effect on cartilage degradation and bone erosion by reducing the synthesis of collagen and proteoglycan by chondrocytes and increasing the expression of the receptor activator of the NF-kB ligand which mediates osteoclast differentiation [66, 76].

Tregs are considered the main regulators of the immune response by suppressing the activity of Th1, Th2, and Th17 cells. Even though several studies have demonstrated that Tregs are present in RA patients, it has been described that the number and function of these cells are impaired in RA. For example, Ehrestein et al. [80] observed a compromised function of Tregs in RA patients that was restored by anti-TNF- $\alpha$ treatment. Besides, effector $\mathrm{T}$ cells from peripheral blood of RA patients can be also resistant to the suppressive effects of Tregs [81]. In this context, the defective function of Tregs in RA largely contributes to disease immunopathogenesis elicited by the exacerbated inflammatory immune response.

Synovial fibroblasts, chondrocytes, and osteoclasts comprise another important group of cells involved in RA immunopathogenesis. Their relevance relies on their role in inflammatory processes that culminate in a more severe disease manifestation including cartilage and bone destruction. Interestingly, synovial fibroblasts are also implicated in RA onset, even though its role in disease triggering is not fully elucidated. It has been suggested that, once activated by the innate immune system, these fibroblasts produce effector molecules such as proteinases that contribute to matrix degradation and also facilitate cartilage and bone destruction [82].

The inflammatory process in RA synovium culminates in joint destruction through cartilage degradation and bone resorption. In this context, chondrocytes and osteoclasts have a key role in the joint structural damage. Chondrocytes respond to the inflammatory microenvironment leading to cartilage remodeling in AR. Once activated, these cells contribute to the degradation of cartilage collagens and proteoglycans through the release of pro-inflammatory cytokines such as IL- 1 and TNF- $\alpha$ that stimulate the production of MMPs by macrophage- and fibroblast-like cells present in the pannus [83]. Osteoclast differentiation is also observed in this RA typical inflammatory tissue in response to the proinflammatory cytokine milieu. These cells are responsible for the bone resorption and consequent structural damage in RA patients [84].

A great deal of data suggests that VitD can interfere in this complex sequence of events that leads, ultimately, to joint destruction. Jeffery et al. [85] recently reviewed the effects of VitD in this disease, stressing the cellular targets of this vitamin in RA and also shedding light on the biochemical pathways that may lead to a consensus regarding the efficacy of VitD supplementation in RA patients. Table 1 summarizes the current knowledge of the possible actions of VitD on RA.

\section{Tolerogenic Effect of Vitamin D in Experimental Arthritis}

\section{Background}

RA treatment usually consists of combined therapies that suppress the entire immune response, leading to increased susceptibility to a plethora of infections. In this sense, many efforts are made to develop more specific immunomodulatory strategies as, for example, the induction of antigen-specific tolerance [86-88]. Self-tolerance can be induced by different procedures such as self-antigen administration via tolerogenic routes (oral mucosa, for example), concomitant blocking of co-stimulatory molecules, or self-antigen targeting to resting antigen-presenting cells, such as DCs [89]. Although traditionally characterized as strong immune response inducers, including during self-reactivity in autoimmune diseases, recent findings implicate DCs in the triggering and maintenance of self-tolerance [90]. Besides VitD3, many other pharmacological agents, including corticosteroids, cyclosporine A, rapamycin, mycophenolate mofetil, and prostaglandin E2, confer tolerogenic properties to DCs with the ensuing induction of Tregs [91, 92].

Based on the immunomodulatory effects of VitD3, mainly on DCs, our research group has been studying the possible 
Table 1 VitD effects and their relevance in RA

\begin{tabular}{|c|c|c|c|}
\hline VitD target & VitD effects & $\begin{array}{l}\text { Possible VitD } \\
\text { action in RA }\end{array}$ & References \\
\hline DCs & $\begin{array}{l}\text { Impairment of } \\
\text { differentiation, } \\
\text { maturation and } \\
\text { activation }\end{array}$ & $\begin{array}{l}\text { Reduction of T cell } \\
\text { activation; } \\
\text { induction of Tregs }\end{array}$ & {$[26,121]$} \\
\hline B cells & $\begin{array}{l}\text { Suppression of } \\
\text { plasma cells; } \\
\text { induction of } \\
\text { Bregs }\end{array}$ & $\begin{array}{l}\text { Decrease in } \\
\text { autoantibody } \\
\text { production and } \\
\text { immune complex } \\
\text { formation }\end{array}$ & {$[122,123]$} \\
\hline Th17 cells & $\begin{array}{l}\text { Inhibition of IL- } \\
\text { 17A production; } \\
\text { impairment of } \\
\text { differentiation }\end{array}$ & $\begin{array}{l}\text { Impairment of bone } \\
\text { erosion; reduction } \\
\text { of synovial } \\
\text { inflammation }\end{array}$ & {$[23,124]$} \\
\hline Tregs & $\begin{array}{l}\text { Increased IL-10 } \\
\text { production and } \\
\text { CTLA-4 expres- } \\
\text { sion }\end{array}$ & $\begin{array}{l}\text { Tregs expansion and } \\
\text { enhancement of } \\
\text { suppressive effects; } \\
\text { inflammation } \\
\text { control }\end{array}$ & {$[102,125]$} \\
\hline $\begin{array}{l}\text { Synovial } \\
\text { fibroblasts }\end{array}$ & $\begin{array}{l}\text { Inhibition of TNF- } \\
\alpha, \text { IL- } 6 \text {, and } \\
\text { MMP, } \\
\text { osteoclastogene- } \\
\text { sis }\end{array}$ & $\begin{array}{l}\text { Reduction of synovial } \\
\text { inflammation; } \\
\text { inhibition of bone } \\
\text { erosion }\end{array}$ & {$[126,127]$} \\
\hline Chondrocytes & $\begin{array}{l}\text { Regulation of } \\
\text { MMP } \\
\text { production }\end{array}$ & $\begin{array}{l}\text { Reduction of cartilage } \\
\text { degradation }\end{array}$ & [128] \\
\hline Osteoclasts & $\begin{array}{l}\text { Inhibition of } \\
\text { osteoclastogene- } \\
\text { sis }\end{array}$ & $\begin{array}{l}\text { Inhibition of bone } \\
\text { resorption }\end{array}$ & [129] \\
\hline
\end{tabular}

VitD vitamin D, DCs dendritic cells, Bregs regulatory B cells, Tregs regulatory T cells, $M M P$ metalloproteinase

role of VitD3 as a tolerogenic adjuvant when associated with a specific antigen. Conceptually, tolerogenic adjuvants combined with specific antigens would down-modulate the specific immune response instead of reinforcing the immune response as conventional adjuvants. We recently demonstrated that the association of VitD3 with a specific antigen from the CNS successfully impaired the development of experimental autoimmune encephalomyelitis. This therapeutic effect was associated with less CNS inflammation and lower production of IL- 6 and IL-17 by spleen and CNS cells [93]. In this scenario, the potential tolerogenic effect of VitD3 associated with proteoglycan (PG), which is a specific cartilage antigen, was also evaluated in experimental arthritis.

\section{Experimental Design}

For experimental arthritis induction, female retired-breeder $\mathrm{BALB} / \mathrm{c}$ mice were injected with bovine PG emulsified in dimethyl dioctadecyl ammonium bromide (DDA) adjuvant. Starting 1 day after disease induction, mice received intraperitoneal VitD3 doses every other day for 15 days. PG was coadministered on the $3 \mathrm{rd}$ and on the 11th day of VitD3 treatment. Twenty-one days after arthritis induction, disease score was evaluated daily until euthanasia. Arthritis severity was assessed as previously described [94], considering a standard visual scoring system based on the degree of edema and erythema ranging from 0 to 4 for each paw. Histopathological analysis, quantification of $\mathrm{T}$ cell subsets, and cytokine levels in mice paws were evaluated at the day of euthanasia, i.e., 70 days after arthritis induction. At the same time, DC and Treg frequencies and cytokine production in the spleen were also determined. This experimental design is summarized in Fig. 2 and a detailed methodology is available in Online Resource 1. Animal manipulation was approved by the local ethics committee for animal experimentation (Comissão de Ética na Experimentação Animal-CEEA), protocol number 257-CEEA

\section{Results}

As expected, animals from the control (-) group did not develop arthritis, whereas the ones from the control (+) group developed very typical arthritis manifestations. Disease incidence in control (+), PG, VitD3, and VitD3+PG groups was similar. However, groups that received VitD3 or VitD3+PG developed a significantly less severe form of arthritis characterized by a lower percentage of animals with a score above 8 . Analysis of the maximum score confirmed a significant reduction in arthritis severity in VitD3 and VitD3+PG-treated groups. Disease onset in the four arthritic groups occurred in the same period, i.e., around day 45 . These results are summarized in Table 2 and Fig. 3.

The histopathological analysis that was assessed by hematoxylin-eosin (HE)-stained paw sections obtained after euthanasia reinforced the clinical follow-up. As anticipated, animals from the control (-) group presented no alterations in joint structures. Figure $4 a, b$ represents a score 0 hind paw of an animal from this group. In this case, the synovial space is well defined, with a very thin synovial membrane, and there is no inflammatory infiltrate. Also, cartilage and bone are clearly preserved. All animals from the PG, VitD3, and VitD3+PG groups presented score paws ranging from 0 to 4 . However, the frequency of these scores was distinct in each group. Animals from control (+) group presented the majority of compromised paws in score 4. A representative histological section of a score 4 hind paw from the control (+) group is shown in Fig. 4c, d. Score 4 paws from control (+) group presented severe edema throughout the paw, involving all joints, with consequent movement impairment (not shown). Inflammation and joint destruction in this histological section were evident and were characterized by synovial membrane thickening, pannus formation, cartilage destruction, and bone erosion (Fig. 4d). Interestingly, an evidently higher frequency of paws with score 0 in the VitD3+PG group was observed. Figure $4 \mathrm{e}, \mathrm{f}$ represents the histological sections of a score 0 


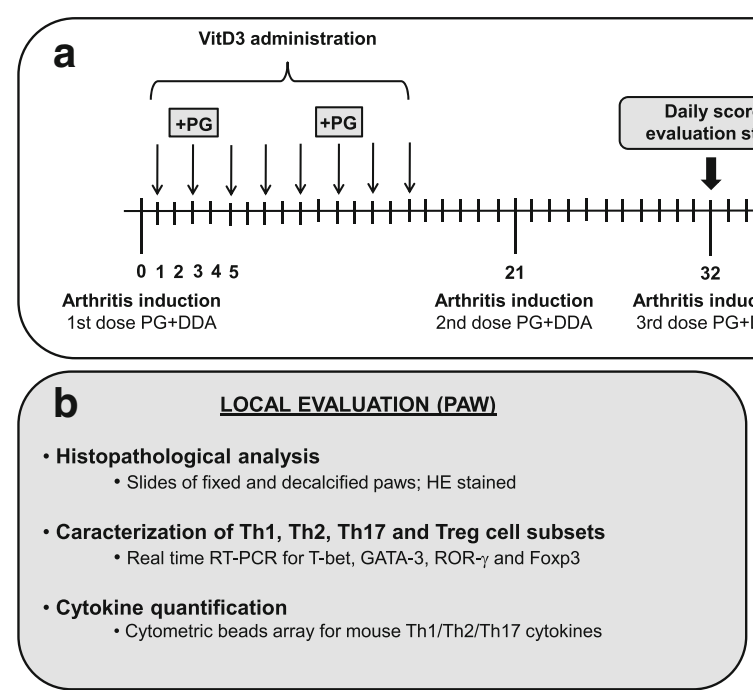

Fig. 2 Schematic representation of the experimental design. Schedule of arthritis induction and 1,25-dihydroxyvitamin D (VitD3) treatment with proteoglycan (PG) concomitant administration (a). Mice paws evaluation after euthanasia at day 70 (b). Immunological splenic evaluation after euthanasia at day $70(\mathbf{c})$

a high frequency of Tregs was present in the control (+) but not in the VitD3 and VitD3+PG groups (Fig. 6b). Moreover, both pro- and anti-inflammatory cytokines were detected in spleen cell cultures. As illustrated in Fig. 7a-f, respectively, spontaneous production of TNF- $\alpha$, IFN- $\gamma$, IL-6, IL-5, and IL10 was observed in non-stimulated cultures from all arthritic groups. However, significantly higher levels of these cytokines were produced after stimulation with the specific antigen (PG), except for IL-6. Only VitD3+PG association significantly reduced the production of TNF- $\alpha$, IFN- $\gamma$, IL-6, IL-17, IL-5, and IL-10 (Fig. 7a-f, respectively) in PGstimulated cultures compared with the control (+) group.

\section{Discussion}

A large body of evidence suggests that VitD3 may be beneficial in autoimmune and allergic pathologies $[14,95]$. In this context, the main objective of this study was to evaluate whether the association of VitD3 and a specific cartilage antigen has an immunomodulatory effect on experimental arthritis. Our data indicate that this association was clearly effective as it significantly decreased the severity of disease. The histopathological analysis confirmed the efficacy of this strategy,
Table 2 Effect of VitD3+PG association on arthritis incidence and severity in $\mathrm{BALB} / \mathrm{c}$ mice

\begin{tabular}{llllll}
\hline & Arthritis incidence & $P$ value & Disease onset (days) & Animals with score 8 & $P$ value \\
\hline Control (+) & $14 / 15(93 \%)$ & 0.913 & 45 & $11 / 15(73 \%)$ & $0.010^{\mathrm{a}}$ \\
PG & $15 / 16(94 \%)$ & & 45 & $7 / 16(43 \%)$ & \\
VitD3 & $14 / 15(93 \%)$ & & 46 & $3 / 15(20 \%)$ & \\
VitD3+PG & $6 / 7(86 \%)$ & & 44 & $1 / 7(14 \%)$ & \\
\hline
\end{tabular}

Control (+) non-treated arthritic group, $P G$ proteoglycan, VitD3 1,25-dihydroxyvitamin D

${ }^{\text {a }}$ Statistical difference revealed by chi-square analysis. Data from two independent experiments were combined 
Fig. 3 Effect of VitD3+PG association on experimental arthritis development. Kinetics of total score (a). Maximum score mean per group (b). Arthritis score and severity were assessed by a visual scoring system with total score ranging from 0 to 16 for each animal. Representative clinical scores from mice hind paws (c). Control (-): non-treated healthy group. Control (+): nontreated arthritic group. Six to ten animals per group from one representative experiment of two performed. $* P 0.05$ a

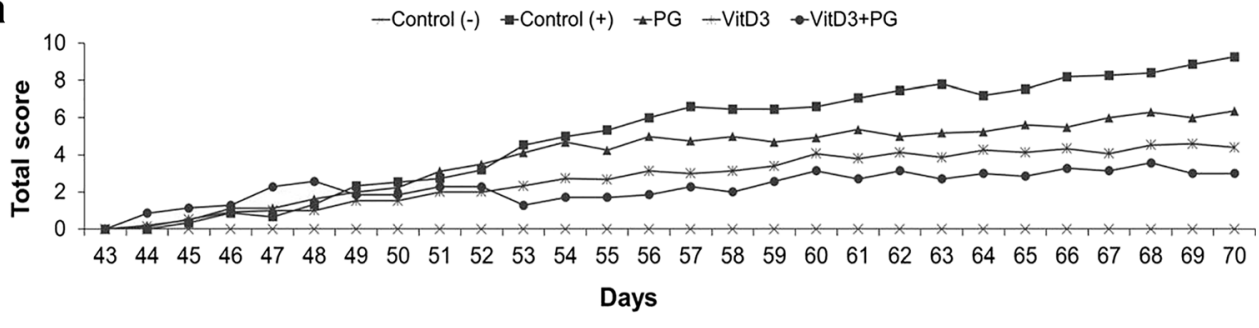

b

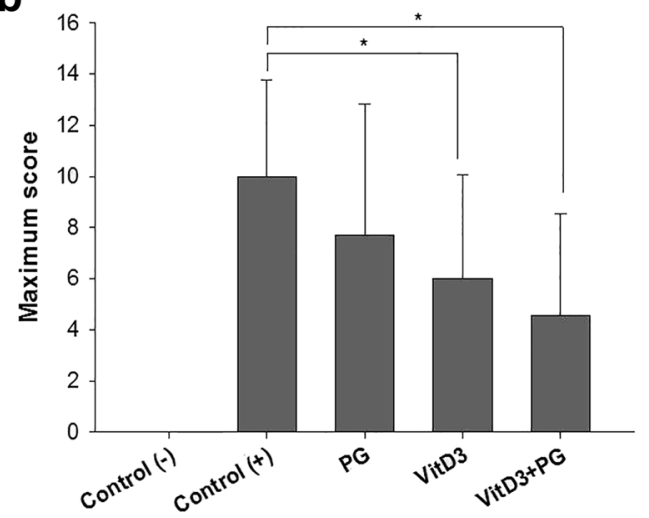

C CLINICAL SCORE

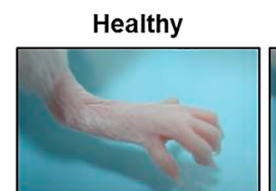

Score 0

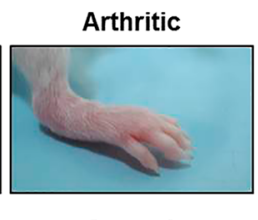

Score 3 showing that a large percentage of joint paws remained preserved, with no structural alterations as inflammation, pannus and cartilage destruction. Earlier data already demonstrated that dietary supplementation with VitD3 given to mice with early symptoms of collagen-induced arthritis prevented progression to severe disease [96]. Some indirect data from humans also suggest that this vitamin can be useful in arthritis. For example, in the study performed by Haga et al. [97], deficiency of VitD3 was detected in $33.4 \%$ of the RA patients. Interestingly, these authors also found that a subset of patients with higher disease activity and requiring treatment with at least three DMARDs were, coincidentally, the ones
Fig. 4 Effect of VitD3+PG association on score frequency and histopathological analysis of paws from arthritic mice. Photomicrographs of HE histological sections from control $(-)(\mathbf{a}, \mathbf{d})$, control $(+)(\mathbf{b}, \mathbf{e})$, and $\mathrm{VitD} 3+\mathrm{PG}(\mathbf{c}, \mathbf{f})$ groups. Mice hind paws were collected 70 days after disease induction. Frequency of the different scores of all mice paws per group (g). Control (-): non-treated healthy group. Control (+): non-treated arthritic group. Boxes indicate $\times 10$ magnification sections presented below their respective $\times 4$ magnification counterparts. Arrows indicate the synovial membrane hypertrophy. $S S$ synovial space; $C$ cartilage; $B$ bone; $P$ pannus; $B O$ bone erosion

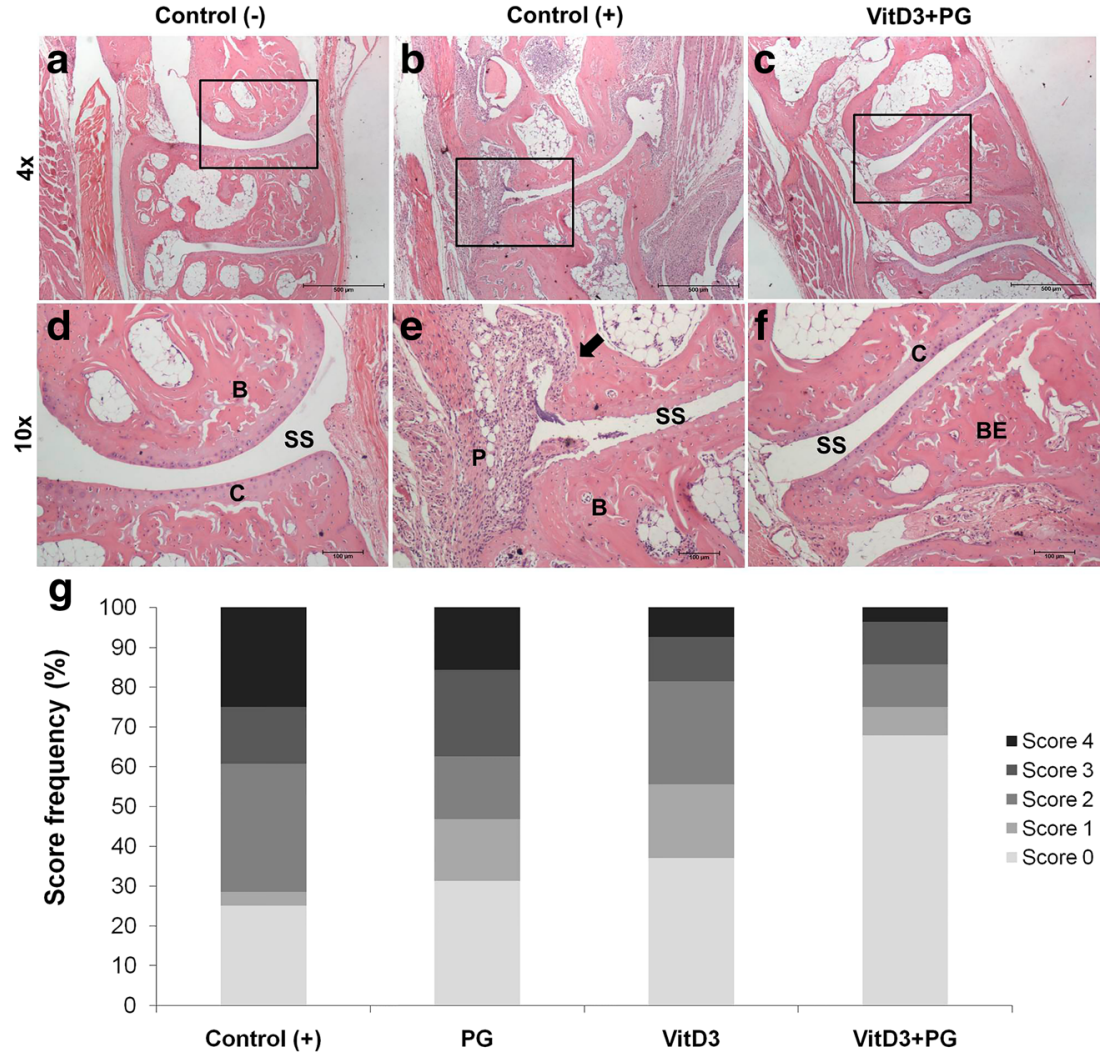


Fig. 5 Effect of VitD3 and PG association on local $\mathrm{T}$ cell subset transcription factors and cytokine levels. T-bet (a), GATA-3 (b), ROR- $\gamma(\mathbf{c})$, and Foxp3 (d) mRNA expression. TNF- $\alpha$ (e) and IL-6 (f) levels in paw homogenates from the experimental groups assessed by cytometric bead array. Quantification was based on fold difference $\left(2^{-\Delta \Delta \mathrm{Ct}}\right)$ between groups, using control (-) group as the calibrator. Control (-): nontreated healthy group. Control (+): non-treated arthritic group. Hind and forepaws from six to ten animals per group from one representative experiment of two performed a
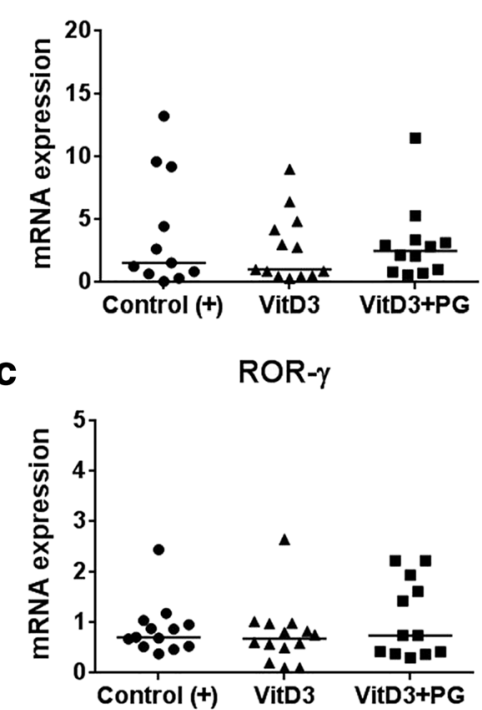

e

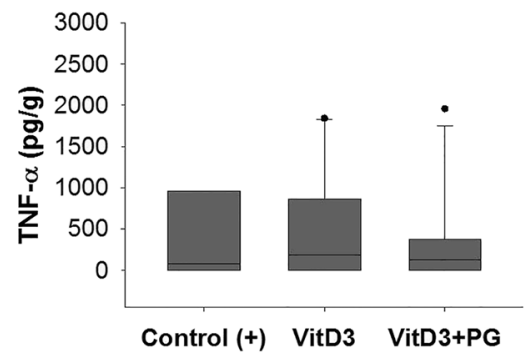

b

GATA-3
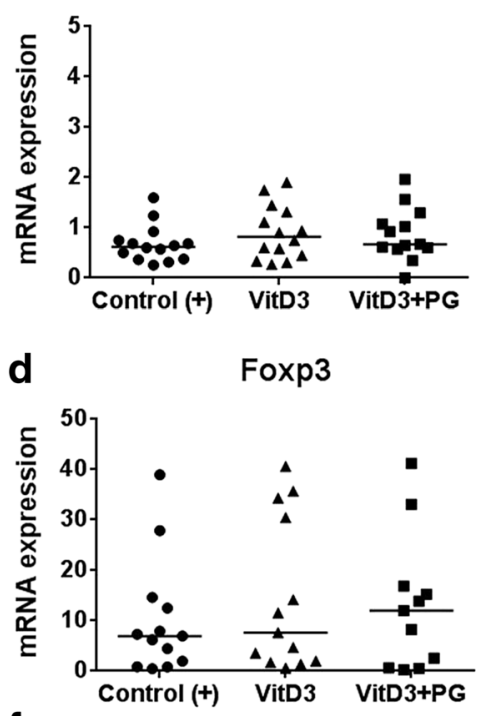

f

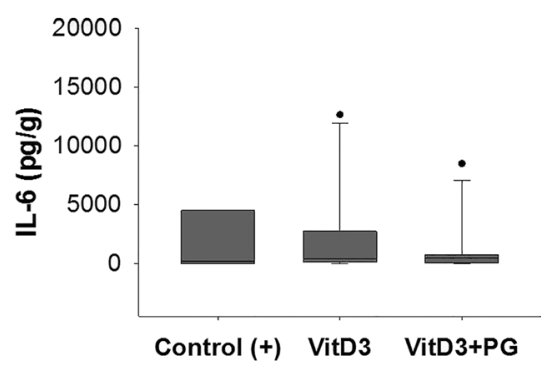

with the most accentuated VitD deficiency. Direct data that could convincingly establish the therapeutic effect of VitD3 on RA is, however, still missing.

To disclose the mechanism by which the association of VitD3 and PG was modulating the course of this disease, the main molecular and cellular targets of VitD3, which are DCs, Tregs, and cytokine production, were evaluated. As VitD3 is able to polarize DCs towards an immature/tolerogenic profile [98], we analyzed the percentage of DCs presenting a more mature phenotype in the spleen by the end of the experiment (day 70), when the immunomodulatory effect was still very clear. However, the expected decrease in the frequency of DC maturation markers such as MHCII and CD80 was not detected after VitD3 treatment. A more encompassing analysis of these cells, including earlier phase assays, will be needed to understand their possible role in the efficacy of arthritis control by VitD3+PG. A few publications have indicated, however, that mature DCs are required for tolerance induction. According to Albert et al. [99], DC maturation is needed for tolerization of $\mathrm{CD} 8+\mathrm{T}$ cells and the critical checkpoint in this tolerance establishment was the absence of co-stimulatory molecules. The contribution of mature DCs to protection against autoimmunity was also clearly demonstrated by Menges et al. [100]. These authors described that injection of DCs matured with TNF- $\alpha$ was able to protect mice from
EAE development. Interestingly, these TNF- $\alpha$ matured DCs expressed high levels of MHCII and co-stimulatory molecules but released very low concentrations of pro-inflammatory cytokines. In this sense, it would be interesting to evaluate the relative production of IL-12 and IL-10 by DCs present in animals that received the $\mathrm{VitD} 3+\mathrm{PG}$ association. Other aspects that deserve attention are the time points and the microenvironment in which DCs were collected. Considering that VitD3 and PG were both injected inside the peritoneal cavity and that the peritoneal space drains, in rodents, to the celiac superior mesenteric and periportal lymph nodes [101], it is conceivable that VitD3+PG effect would be more accentuated in these lymphoid organs.

Currently, the most well-known Treg subset is identified as being $\mathrm{CD} 4^{+} \mathrm{CD} 25^{\text {high }}$ Foxp $3^{+}$. As increased VitD availability is being positively correlated with expansion of these Tregs [102] and with the reduced severity of autoimmune experimental diseases [103], a higher proportion of these cells was expected in mice that received VitD3 or VitD3+PG association. Distinctively from our expectation, only the control (+) group presented higher frequency of $\mathrm{CD} 25^{+} \mathrm{Foxp} 3^{+}$Tregs. Although unexpected, this result is consistent with the finding that RA patients present increased numbers of circulating Tregs even though the suppressive function of these cells is compromised and favors ongoing inflammation [104]. 


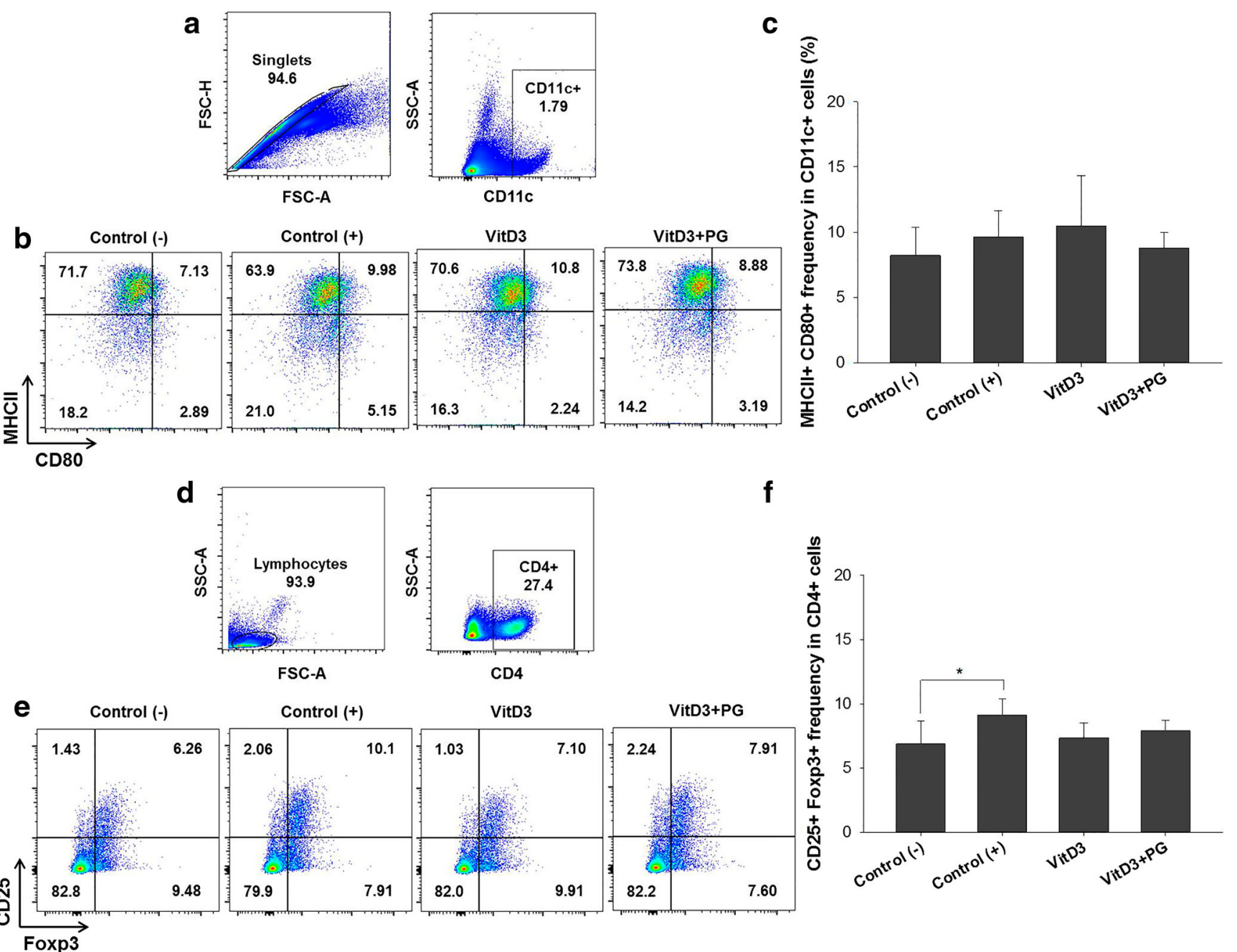

Fig. 6 Effect of VitD3+PG association on the frequency of splenic dendritic and regulatory $\mathrm{T}$ cells in arthritic mice. Gate strategy for DCs (a). Representative dot plots for DCs frequency in spleen (b). MHCII+ CD80+ cell frequency in total CD11+ cells $(\mathbf{c})$. Gate strategy for Tregs

The immunomodulatory effect of VitD3+PG on proinflammatory cytokine production by spleen cells was impressive. TNF- $\alpha$, IL-6, IFN- $\gamma$, and IL-17 were clearly down-modulated by this association. The immunomodulatory effect of VitD3 in allergies, infections, and autoimmune diseases has been demonstrated in both human and experimental models [103, 105-107]. Specifically in relation to RA, VitD3 has determined a significant protective effect associated with reduced production of pro-inflammatory cytokines $[96,108]$. In this context, the decrease of IL-10 production in response to the specific stimulus was not expected. However, there are conflicting data concerning the effect of VitD3 on IL-10 levels in both experimental models and RA patients. For example, Bemiss et al. [109] demonstrated that the in vitro addition of VitD3 significantly decreased IFN- $\gamma$ and IL-10 production by splenocytes from wild-type C57BL/6 mice stimulated with ConA. Moreover, Niino et al. [110] showed that VitD3 suppresses IL-10 production by human monocyte cultures from (d). Representative dot plots for Tregs frequency in spleen (e). CD25+ Foxp3+ cell frequency in total CD4+ cells (f). Control (-): non-treated healthy group. Control (+): non-treated arthritic group. Six to ten animals per group from one representative experiment of two performed. $* P 0.05$

patients with multiple sclerosis. IL-10 up- or downmodulation elicited by VitD3 is attributed not only to the different cells types studied but also to the duration of VitD3 treatment and the evaluation time points [111].

Overall, the analysis of cytokine production showed that VitD3 by itself was already decreasing the production of all of the evaluated cytokines. As this experimental group also presented a significant reduction in arthritis severity, we conclude that VitD3 plays a relevant role in this immunomodulatory effect. However, there is also an important contribution of PG. Even though PG alone did not modify cytokine production, animals that received VitD3+PG association produced significantly lower cytokine levels after specific stimulation. The therapeutic effect of VitD3 is already well documented in experimental arthritis $[112,113]$; however, our results constitute the first direct in vivo assessment of its tolerogenic potential. Recently, it was demonstrated that the association of VitD3 with myelin oligodendrocyte glycoprotein-derived 
Fig. 7 Effect of VitD3+PG association on cytokine production by spleen cells from arthritic mice. TNF- $\alpha(\mathbf{a})$, IL-6 (b), IFN- $\gamma(\mathbf{c})$, IL17 (d), IL-5 (e), and IL-10 (f) production by spleen cells stimulated in vitro with PG. Cytokine levels were detected by ELISA. Control $(-)$ : non-treated healthy group. Control (+): non-treated arthritic group. Six to ten animals per group from one representative experiment of two performed. $* p \quad 0.05$ compared to non-stimulated counterpart and $* * p \quad 0.05$ compared to the control (+) group a

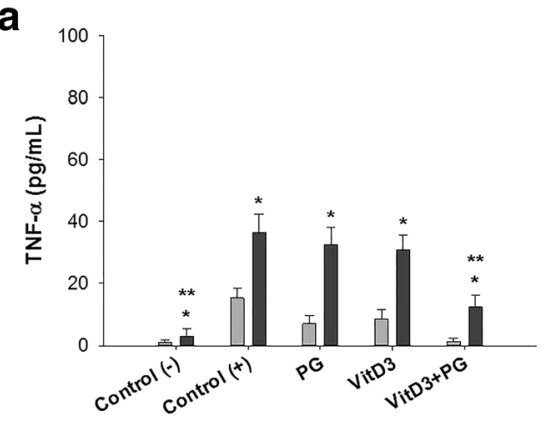

C

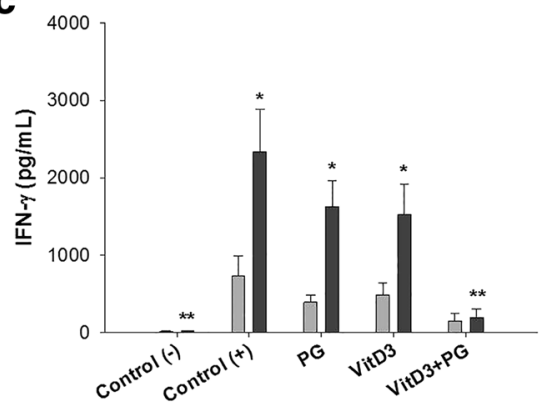

e

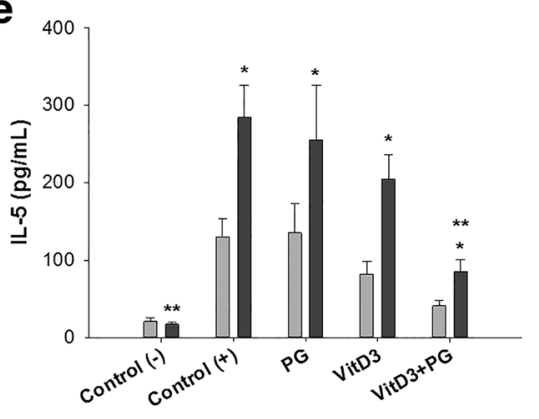

b

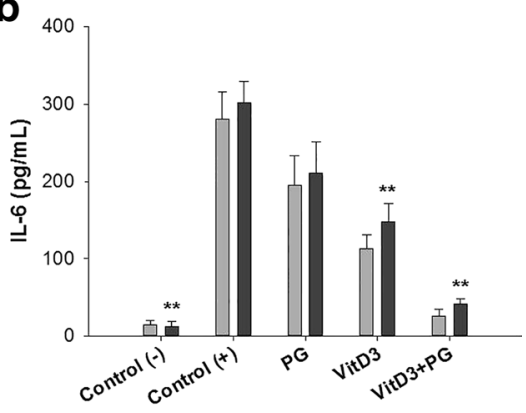

d

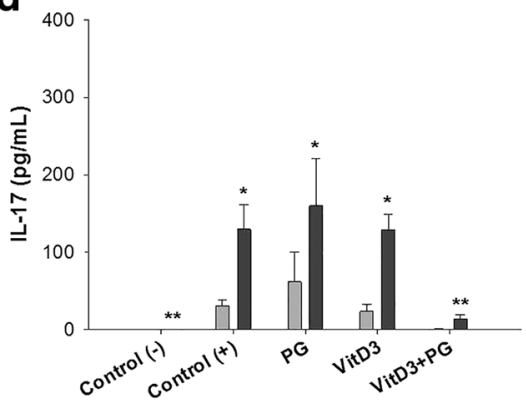

f

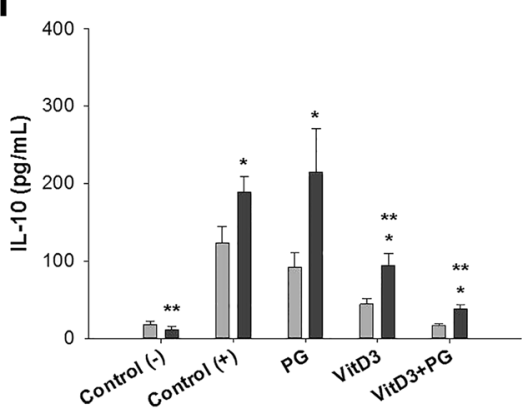

peptide completely abrogated EAE development in C57BL/6 mice [93]. The concept of tolerogenic adjuvants is based on the ability of certain substances, mainly immunosuppressants and immunoregulators, to downregulate unwanted immune responses and induce immune tolerance [114]. In this scenario, we consider PG, in the presence of VitD3, to be inducing a state of tolerance towards itself. This tolerizing condition would result in a decreased production of cytokines detected by an in vitro recall response. The fact that cytokine production induced by ConA was similar in all experimental groups (data not shown) strengthens the interpretation of a specific tolerance induction. The efficacy of this concept was already described in other autoimmune experimental diseases. Kang et al. [115], for example, demonstrated that immunization of mice with MOG associated with FK506, which is a widely used immunosupressant, induced antigen-specific tolerance and prevented the development of EAE. In another EAE model, it was described that IFN- $\beta$ can also behave as a tolerogenic adjuvant being able to induce neuroantigen-associated tolerance [116].
Some aspects of this immunomodulatory effect deserve to be highlighted considering a possible future translation of these experimental findings to patients. First of all, this strategy started at an early phase of the experimental disease which could correspond to a preclinical phase in humans. Currently, RA therapy is postponed until the patient shows clinical symptoms [117]. However, we could envision that future therapies for this pathology can be initiated during the preclinical phase because some preclinical markers such as antiCCP antibodies are already detected in the serum [118, 119]. It is important to also stress that this therapeutic effect could be improved by other rounds of $\mathrm{VitD} 3+\mathrm{PG}$ administration.

Our study indicated that the early administration of VitD3 associated with the specific antigen, $\mathrm{PG}$ in this case, controlled arthritis severity. The results also suggested that VitD3 played a role as a tolerogenic adjuvant significantly decreasing cytokine production. Further experiments will be necessary to 
evaluate whether Tregs are present, at earlier periods, in the arthritic lesions.

\section{Concluding Remarks}

Despite some controversies, the majority of the reports reinforce the idea that lower VitD levels correlate with more severe clinical manifestations in RA patients. Therefore, supplementation with VitD to achieve normal serum levels is worthwhile as an aforethought. Considering the tolerogenic effect of VitD3 associated with PG suggested by our study, further investigations will reveal its plausible use in human RA. Regarding this, many other self-antigens such as immunoglobulin G, collagen, citrulline, calpastatin, calreticulin, fibrin, and fibrinogen are possibly involved in this autoimmune process [120]. In this scenario, it is expected that the combination of one or more joint specific antigen with VitD3 could determine a state of tolerance that would protect the joint. Considering the current RA treatments, which are mainly based on combined therapies, further studies will also be necessary to test the effectiveness of VitD with drugs that are already in use, as, for example, methotrexate.

Acknowledgments The authors are thankful to São Paulo State Foundation (FAPESP) for the financial support. Special thanks are given to Prof. Yehuda Shoenfeld, Mrs. Anna Varsanyi, and the Federico Fellows from the Zabludowicz Center for Autoimmune Diseases, Israel, for the scientific contribution.

\section{Compliance with Ethical Standards}

Conflict of Interest The authors declare that they have no conflict of interest.

Funding This study was funded by São Paulo State Foundation (grant no. 2011/17325-4 and grant no. 2010/20470-3).

Ethical Approval All applicable international, national, and/or institutional guidelines for the care and use of animals were followed. All procedures performed in studies involving animals were in accordance with the ethical standards of the institution or practice at which the studies were conducted.

\section{References}

1. Lamberg-Allardt C (2006) Vitamin D in foods and as supplements. Prog Biophys Mol Biol 92:33-38. doi:10.1016/j. pbiomolbio.2006.02.017

2. Aranow C (2011) Vitamin D and the immune system. J Investig Med 59:881-886. doi:10.231/JIM.0b013e31821b8755

3. Holick MF (2003) Vitamin D: a millennium perspective. J Cell Biochem 88:296-307. doi:10.1002/jcb.10338

4. Dusso AS, Brown AJ, Slatopolsky E (2005) Vitamin D. Am J Physiol Renal Physiol 289:F8-28. doi:10.1152 /ajprenal.00336.2004
5. Zhang J, Habiel DM, Ramadass M, Kew RR (2010) Identification of two distinct cell binding sequences in the vitamin D binding protein. Biochim Biophys Acta 1803:623639. doi:10.1016/j.bbamcr.2010.02.010

6. Suzuki Y, Landowski CP, Hediger MA (2008) Mechanisms and regulation of epithelial $\mathrm{Ca}^{2+}$ absorption in health and disease. Annu Rev Physiol 70:257-271. doi:10.1146/annurev. physiol.69.031905.161003

7. Holick MF (2011) Vitamin D deficiency in 2010: health benefits of vitamin D and sunlight: a D-bate. Nat Rev Endocrinol 7:73-75. doi: $10.1038 /$ nrendo.2010.234

8. Holick MF, Binkley NC, Bischoff-Ferrari HA, Gordon CM, Hanley DA, Heaney RP, Murad MH, Weaver CM, Endocrine Society (2011) Evaluation, treatment, and prevention of vitamin D deficiency: an Endocrine Society clinical practice guideline. J Clin Endocrinol Metab 96:1911-1930. doi:10.1210/jc.2011-0385

9. Adorini L, Penna G (2009) Dendritic cell tolerogenicity: a key mechanism in immunomodulation by vitamin $\mathrm{D}$ receptor agonists. Hum Immunol 70:345-352. doi:10.1016/j.humimm.2009.01.016

10. Norman AW, Okamura WH, Bishop JE, Henry HL (2002) Update on biological actions of 1alpha,25(OH)2-vitamin D3 (rapid effects) and 24R,25(OH)2-vitamin D3. Mol Cell Endocrinol 197: 1-13. doi:10.1016/S0303-7207(02)00273-3

11. Kongsbak M, Levring TB, Geisler C, von Essen MR (2013) The vitamin D receptor and T cell function. Front Immunol 4:148. doi:10.3389/fimmu.2013.0014

12. Carlberg C, Polly P (1998) Gene regulation by vitamin D3. Crit Rev Eukaryot Gene Expr 8:19-42. doi:10.1615 /CritRevEukarGeneExpr.v8.i1.20

13. Holick MF (2007) Vitamin D deficiency. N Engl J Med 357:266281. doi:10.1056/NEJMra070553

14. Agmon-Levin N, Theodor E, Segal RM, Shoenfeld Y (2014) Vitamin $\mathrm{D}$ in systemic and organ-specific autoimmune diseases. Clin Rev Allergy Immunol 45:256-266. doi:10.1007/s12016-012-8342-y

15. Kroner Jde C, Sommer A, Fabri M (2015) Vitamin D every day to keep the infection away? Nutrients 7:4170-4188. doi:10.3390 /nu7064170

16. Nouari W, Ysmail-Dahlouk L, Aribi M (2016) Vitamin D3 enhances bactericidal activity of macrophage against Pseudomonas aeruginosa. Int Immunopharmacol 30:94-101. doi:10.1016/j.intimp.2015.11.033

17. Di Rosa M, Malaguarnera M, Nicoletti F, Malaguarnera L (2011) Vitamin D3: a helpful immuno-modulator. Immunology 134:123139. doi:10.1111/j.1365-2567.2011.03482.x

18. Cantorna MT, Snyder L, Lin YD, Yang L (2015) Vitamin D and 1, 25(OH)2D regulation of T cells. Nutrients 7:3011-3021. doi:10.3390/nu7043011

19. Lemire JM, Archer DC, Beck L, Spiegelberg HL (1995) Immunosuppressive actions of 1,25-dihydroxyvitamin D3: preferential inhibition of Th1 functions. J Nutr 125:1704S-1708S

20. Boonstra A, Barrat FJ, Crain C, Heath VL, Savelkoul HF, O'Garra A (2001) 1alpha,25-Dihydroxyvitamin d3 has a direct effect on naive CD4(+) T cells to enhance the development of Th2 cells. J Immunol 167:4974 4980. doi:10.4049/jimmunol.167.9.4974

21. Staeva-Vieira TP, Freedman LP (2002) 1,25-dihydroxyvitamin D3 inhibits IFN-gamma and IL-4 levels during in vitro polarization of primary murine CD4+ T cells. J Immunol 168:1181-1189. doi:10.4049/jimmunol.168.3.1181

22. Singh RP, Hasan S, Sharma S, Nagra S, Yamaguchi DT, Wong DT, Hahn BH, Hossain A (2014) Th17 cells in inflammation and autoimmunity. Autoimmun Rev 13:1174-1181. doi:10.1016/j.autrev.2014.08.019

23. Fawaz L, Mrad MF, Kazan JM, Sayegh S, Akika R, Khoury SJ (2016) Comparative effect of 25(OH)D3 and 1,25(OH)2D3 on Th17 cell differentiation. Clin Immunol 166-167:59-71. doi:10.1016/j.clim.2016.02.011 
24. Tang J, Zhou R, Luger D, Zhu W, Silver PB, Grajewski RS, Su SB, Chan CC, Adorini L, Caspi RR (2009) Calcitriol suppresses antiretinal autoimmunity through inhibitory effects on the Th17 effector response. J Immunol 182:4624 4632. doi:10.4049/jimmunol.0801543

25. Chang JH, Cha HR, Lee DS, Seo KY, Kweon MN (2010) 1,25Dihydroxyvitamin D3 inhibits the differentiation and migration of $\mathrm{T}(\mathrm{H}) 17$ cells to protect against experimental autoimmune encephalomyelitis. PLoS One 5:e12925. doi:10.1371/journal.pone.0012925

26. Berer A, Stöckl J, Majdic O, Wagner T, Kollars M, Lechner K, Geissler K, Oehler L (2000) 1,25-Dihydroxyvitamin D(3) inhibits dendritic cell differentiation and maturation in vitro. Exp Hematol 28:575-583. doi:10.1016/S0301-472X(00)00143-0

27. Adler HS, Steinbrink K (2007) Tolerogenic dendritic cells in health and disease: friend and foe! Eur J Dermatol 17:476-491. doi:10.1684/ejd.2007.0262

28. Sakaguchi S, Miyara M, Costantino CM, Hafler DA (2010) FOXP3+ regulatory $\mathrm{T}$ cells in the human immune system. Nat Rev Immunol 10:490-500. doi:10.1038/nri2785

29. Penna G, Roncari A, Amuchastegui S, Daniel KC, Berti E, Colonna M, Adorini L (2005) Expression of the inhibitory receptor ILT3 on dendritic cells is dispensable for induction of CD4+ Foxp3+ regulatory $\mathrm{T}$ cells by 1,25 -dihydroxyvitamin D3. Blood 106:3490-3497. doi:10.1182/blood-2005-05-2044

30. Gregori S, Giarratana N, Smiroldo S, Uskokovic M, Adorini L (2002) A 1alpha,25-dihydroxyvitamin D(3) analog enhances regulatory T-cells and arrests autoimmune diabetes in NOD mice. Diabetes 51:1367-1374. doi:10.2337/diabetes.51.5.1367

31. Smolders J, Thewissen M, Peelen E, Menheere P, Tervaert JW, Damoiseaux J, Hupperts R (2009) Vitamin D status is positively correlated with regulatory $\mathrm{T}$ cell function in patients with multiple sclerosis. PLoS One 4:e6635. doi:10.1371/journal.pone.0006635

32. Spach KM, Nashold FE, Dittel BN, Hayes CE (2006) IL-10 signaling is essential for 1,25-dihydroxyvitamin D3-mediated inhibition of experimental autoimmune encephalomyelitis. J Immunol 177:6030-6037. doi:10.4049/jimmunol.177.9.6030

33. Pelajo CF, Lopez-Benitez JM, Miller LC (2010) Vitamin D and autoimmune rheumatologic disorders. Autoimmun Rev 9:507510. doi:10.1016/j.autrev.2010.02.011

34. Ponsonby AL, Lucas RM, van der Mei IA (2005) UVR, vitamin D and three autoimmune diseases - multiple sclerosis, type 1 diabetes, rheumatoid arthritis. Photochem Photobiol 81:1267-1275. doi:10.1562/2005-02-15-IR-441

35. Grazio S, Naglić ĐB, Anić B, Grubišić F, Bobek D, Bakula M, Kavanagh HS, Kuna AT, Cvijetić S (2015) Vitamin D serum level, disease activity and functional ability in different rheumatic patients. Am J Med Sci 349:46-49. doi:10.1097/MAJ.0000000000000340

36. Durmus B, Altay Z, Baysal O, Ersoy Y (2012) Does vitamin D affect disease severity in patients with ankylosing spondylitis? Chin Med J (Engl) 125:2511-2515. doi:10.3760/cma.j.issn.0366-6999.2012.14.021

37. Zold E, Szodoray P, Gaal J, Kappelmayer J, Csathy L, Gyimesi E, Zeher M, Szegedi G, Bodolay E (2008) Vitamin D deficiency in undifferentiated connective tissue disease. Arthritis Res Ther 10: R123. doi:10.1186/ar2533

38. Touma Z, Eder L, Zisman D, Feld J, Chandran V, Rosen CF, Shen H, Cook RJ, Gladman DD (2011) Seasonal variation in vitamin D levels in psoriatic arthritis patients from different latitudes and its association with clinical outcomes. Arthritis Care Res (Hoboken) 63:1440-1447. doi:10.1002/acr.20530

39. Gatenby P, Lucas R, Swaminathan A (2013) Vitamin D deficiency and risk for rheumatic diseases: an update. Curr Opin Rheumatol 25:184-191. doi:10.1097/BOR.0b013e32835cfc16

40. Caramaschi P, Dalla Gassa A, Ruzzenente O, Volpe A, Ravagnani V, Tinazzi I, Barausse G, Bambara LM, Biasi D (2010) Very low levels of vitamin D in systemic sclerosis patients. Clin Rheumatol 29:1419-1425. doi:10.1007/s10067-010-1478-3
41. Arnson Y, Amital H, Agmon-Levin N, Alon D, Sánchez-Castañón M, López-Hoyos M, Matucci-Cerinic M, Szücs G, Shapira Y, Szekanecz Z, Shoenfeld Y (2011) Serum 25-OH vitamin D concentrations are linked with various clinical aspects in patients with systemic sclerosis: a retrospective cohort study and review of the literature. Autoimmun Rev 10:490-494. doi:10.1016/j. autrev.2011.02.002

42. Bivona G, Agnello L, Pivetti A, Milano S, Scazzone C, Sasso BL, Ciaccio M (2016) Association between hypovitaminosis D and systemic sclerosis: true or fake? Clin Chim Acta 458:115-119. doi:10.1016/j.cca.2016.04.026

43. Cutolo M, Otsa K, Paolino S, Yprus M, Veldi T, Seriolo B (2009) Vitamin D involvement in rheumatoid arthritis and systemic lupus erythematosus. Ann Rheum Dis 68:446-447. doi:10.1136/ard.2008.093476

44. Mok CC, Birmingham DJ, Leung HW, Hebert LA, Song H, Rovin BH (2012) Vitamin D levels in Chinese patients with systemic lupus erythematosus: relationship with disease activity, vascular risk factors and atherosclerosis. Rheumatology (Oxford) 51:644 52. doi:10.1093/rheumatology/ker212

45. Azrielant S, Shoenfeld Y (2016) Eppur Si Muove: vitamin D is essential in preventing and modulating SLE. Lupus 25:563-572. doi: 10.1177/0961203316629001

46. Gao CC, Liu SY, Wu ZZ, Li TF, Gao GM, Liu ZS, Zheng ZH (2016) Severe vitamin $D$ deficiency increases the risk for moderate to severe disease activity in Chinese patients with SLE. Lupus. doi: 10.1177/0961203316635289

47. Watad A, Neumann SG, Soriano A, Amital H, Shoenfeld Y (2016) Vitamin D and systemic lupus erythematosus: myth or reality? Isr Med Assoc J 18:177-182

48. Robinson A, Tangpricha V, Yow E, Gurion R, Schanberg LE, McComsey GA (2014) Vitamin D status is a determinant of atorvastatin effect on carotid intima medial thickening progression rate in children with lupus: an Atherosclerosis Prevention in Pediatric Lupus Erythematosus (APPLE) sub-study. Lupus Sci Med 10:e000037. doi:10.1136/lupus-2014-000037

49. Schoindre Y, Jallouli M, Tanguy ML, Ghillani P, Galicier L, Aumaître $\mathrm{O}$, Francès C, Le Guern V, Lioté F, Smail A, Limal N, Perard L, Desmurs-Clavel H, Le Thi HD, Asli B, Kahn JE, Sailler L, Ackermann F, Papo T, Sacré K, Fain O, Stirnemann J, Cacoub P, Leroux G, Cohen-Bittan J, Hulot JS, Lechat P, Musset L, Piette JC, Amoura Z, Souberbielle JC, Costedoat-Chalumeau N, Group PLUS (2014) Lower vitamin D levels are associated with higher systemic lupus erythematosus activity, but not predictive of disease flare-up. Lupus Sci Med 1:e000027. doi:10.1136/lupus-2014-000027

50. Petri M, Bello KJ, Fang H, Magder LS (2013) Vitamin D in systemic lupus erythematosus: modest association with disease activity and the urine protein-to-creatinine ratio. Arthritis Rheum 65:1865-71. doi:10.1002/art.37953

51. Mao S, Huang S (2014) Association between vitamin D receptor gene BsmI, FokI, ApaI and TaqI polymorphisms and the risk of systemic lupus erythematosus: a meta-analysis. Rheumatol Int 34: 381-388. doi:10.1007/s00296-013-2898-6

52. Kuhn A, Wenzel J, Bijl M (2016) Lupus erythematosus revisited. Semin Immunopathol 38:97-112. doi:10.1007/s00281-015-05500

53. Tabasi N, Rastin M, Mahmoudi M, Ghoryani M, Mirfeizi Z, Rabe SZ, Reihani H (2015) Influence of vitamin D on cell cycle, apoptosis, and some apoptosis-related molecules in systemic lupus erythematosus. Iran J Basic Med Sci 18:1107-1111

54. Rosen Y, Daich J, Soliman I, Brathwaite E, Shoenfeld Y (2016) Vitamin D and autoimmunity. Scand J Rheumatol 18:1-9. doi:10.3109/03009742.2016.1151072

55. Quintero OL, Amador-Patarroyo MJ, Montoya-Ortiz G, RojasVillarraga A, Anaya JM (2012) Autoimmune disease and gender: 
plausible mechanisms for the female predominance of autoimmunity. J Autoimmun 38:J109-119. doi:10.1016/j.jaut.2011.10.003

56. Boissier MC, Semerano L, Challal S, Saidenberg-Kermanac'h N, Falgarone G (2012) Rheumatoid arthritis: from autoimmunity to synovitis and joint destruction. J Autoimmun 39:222-228. doi:10.1016/j.jaut.2012.05.021

57. Raczkiewicz A, Kisiel B, Kulig M, Tłustochowicz W (2015) Vitamin D status and its association with quality of life, physical activity, and disease activity in rheumatoid arthritis patients. J Clin Rheumatol 21:126-30. doi:10.1097/RHU.0000000000000233

58. Lin J, Liu J, Davies ML, Chen W (2016) Serum vitamin D level and rheumatoid arthritis disease activity: review and meta-analysis. PLoS One 11(1):e0146351. doi:10.1371/journal. pone. 0146351

59. Gopinath K, Danda D (2011) Supplementation of 1,25dihydroxyvitamin D3 in patients with treatment naive early rheumatoid arthritis: a randomized controlled trial. Int J Rheum Dis 14:332-339. doi:10.1111/j.1756-185X.2011.01684.x

60. Salesi M, Farajzadegan Z (2012) Efficacy of vitamin D in patients with active rheumatoid arthritis receiving methotrexate therapy. Rheumatol Int 32:2129-33. doi:10.1007/s00296-011-1944-5

61. Abrahamsen B, Harvey NC (2013) The role of vitamin D supplementation in patients with rheumatic diseases. Nat Rev Rheumatol 9:411-422. doi:10.1038/nrrheum.2013.71

62. Rossini M, Bagnato G, Frediani B, Iagnocco A, LA Montagna G, Minisola G, Caminiti M, Varenna M, Adami S (2011) Relationship of focal erosions, bone mineral density, and parathyroid hormone in rheumatoid arthritis. J Rheumatol 38:997-1002. doi:10.3899/jrheum.100829

63. Firestein GS (2003) Evolving concepts of rheumatoid arthritis. Nature 423:356-361. doi:10.1038/nature01661

64. Kinne RW, Stuhlmüller B, Burmester GR (2007) Cells of the synovium in rheumatoid arthritis. Macrophages. Arthritis Res Ther 9:224. doi:10.1186/ar2333

65. Valencia X, Stephens G, Goldbach-Mansky R, Wilson M, Shevach EM, Lipsky PE (2006) TNF down-modulates the function of human CD4+CD25hi T-regulatory cells. Blood 108:253261. doi:10.1182/blood-2005-11-4567

66. Brzustewicz E, Bryl E (2015) The role of cytokines in the pathogenesis of rheumatoid arthritis - practical and potential application of cytokines as biomarkers and targets of personalized therapy. Cytokine 76:527-36. doi:10.1016/j.cyto.2015.08.260

67. Mateen S, Zafar A, Moin S, Khan AQ, Zubair S (2016) Understanding the role of cytokines in the pathogenesis of rheumatoid arthritis. Clin Chim Acta 455:161-171. doi:10.1016/j. cca.2016.02.010

68. Tanaka Y (2016) Current concepts in the management of rheumatoid arthritis. Korean J Intern Med 31:210-218. doi:10.3904 /kjim.2015.137

69. Hopp AK, Rupp A, Lukacs-Kornek V (2014) Self-antigen presentation by dendritic cells in autoimmunity. Front Immunol 5:55. doi:10.3389/fimmu.2014.00055

70. Catrina AI, Joshua V, Klareskog L, Malmström V (2016) Mechanisms involved in triggering rheumatoid arthritis. Immunol Rev 269:162-174. doi:10.1111/imr.12379

71. Lutzky V, Hannawi S, Thomas R (2007) Cells of the synovium in rheumatoid arthritis. Dendritic cells Arthritis Res Ther 9:219. doi:10.1186/ar2200

72. Martinez-Gamboa L, Brezinschek HP, Burmester GR, Dörner T (2006) Immunopathologic role of B lymphocytes in rheumatoid arthritis: rationale of B cell-directed therapy. Autoimmun Rev 5: 437-442. doi:10.1016/j.autrev.2006.02.004

73. Aletaha D, Blüml S (2016) Therapeutic implications of autoantibodies in rheumatoid arthritis. RMD Open 2:e000009. doi:10.1136/rmdopen-2014-000009
74. van der Helm-van Mil AH, Verpoort KN, Breedveld FC, Huizinga TW, Toes RE, de Vries RR (2006) The HLA-DRB1 shared epitope alleles are primarily a risk factor for anti-cyclic citrullinated peptide antibodies and are not an independent risk factor for the development of rheumatoid arthritis. Arthritis Rheum 54:11171121. doi:10.1002/art.21739

75. Lundy SK, Sarkar S, Tesmer LA, Fox DA (2007) Cells of the synovium in rheumatoid arthritis. T lymphocytes Arthritis Res Ther 9:202. doi:10.1186/ar2107

76. Komatsu N, Takayanagi H (2015) Arthritogenic T cells in autoimmune arthritis. Int $\mathrm{J}$ Biochem Cell Biol 58:92-96. doi:10.1016/j.biocel.2014.11.008

77. Prots I, Skapenko A, Wendler J, Mattyasovszky S, Yoné CL, Spriewald B, Burkhardt H, Rau R, Kalden JR, Lipsky PE, Schulze-Koops H (2006) Association of the IL4R singlenucleotide polymorphism I50V with rapidly erosive rheumatoid arthritis. Arthritis Rheum 54:1491-1500. doi:10.1002/art.21832

78. Kleinewietfeld M, Hafler DA (2013) The plasticity of human Treg and Th17 cells and its role in autoimmunity. Semin Immunol 25: 305-312. doi:10.1016/j.smim.2013.10.009

79. Chabaud M, Durand JM, Buchs N, Fossiez F, Page G, Frappart L, Miossec P (1999) Human interleukin-17: a T cell-derived proinflammatory cytokine produced by the rheumatoid synovium. Arthritis Rheum 42:963-970. doi:10.1002/1529-0131(199905)42:5<963::AID-ANR15>3.0. CO;2-E

80. Ehrenstein MR, Evans JG, Singh A, Moore S, Warnes G, Isenberg DA, Mauri C (2004) Compromised function of regulatory T cells in rheumatoid arthritis and reversal by anti-TNF-alpha therapy. J Exp Med 200:277-285. doi:10.1084/jem.20040165

81. van Amelsfort JM, Jacobs KM, Bijlsma JW, Lafeber FP, Taams LS (2004) CD4(+)CD25(+) regulatory T cells in rheumatoid arthritis: differences in the presence, phenotype, and function between peripheral blood and synovial fluid. Arthritis Rheum 50: 2775-2785. doi:10.1002/art.20499

82. Turner JD, Filer A (2015) The role of the synovial fibroblast in rheumatoid arthritis pathogenesis. Curr Opin Rheumatol 27:175182. doi:10.1097/BOR.0000000000000148

83. Otero M, Goldring MB (2007) Cells of the synovium in rheumatoid arthritis. Chondrocytes Arthritis Res Ther 9:220. doi:10.1186 /ar2292

84. Schett G (2007) Cells of the synovium in rheumatoid arthritis. Osteoclasts. Arthritis Res Ther 9:203. doi:10.1186/ar2110

85. Jeffery LE, Raza K, Hewison M (2016) Vitamin D in rheumatoid arthritis - towards clinical application. Nat Rev Rheumatol 12: 201-210. doi:10.1038/nrrheum.2015.140

86. Tengvall S, Eneljung T, Jirholt P, Turesson O, Wing K, Holmdahl R, Kihlberg J, Stern A, Mårtensson IL, Henningsson L, Gustafsson K, Gjertsson I (2016) Gene therapy induces antigenspecific tolerance in experimental collagen-induced arthritis. PLoS One 11:e0154630. doi:10.1371/journal.pone.0154630

87. Fousteri G, Jofra T, Di Fonte R, Battaglia M (2015) Combination of an antigen-specific therapy and an immunomodulatory treatment to simultaneous block recurrent autoimmunity and alloreactivity in non-obese diabetic mice. PLoS One 10:e0127631. doi:10.1371/journal.pone.0127631

88. Kleist C, Mohr E, Gaikwad S, Dittmar L, Kuerten S, Platten M, Mier W, Schmitt M, Opelz G, Terness P (2016) Autoantigenspecific immunosuppression with tolerogenic peripheral blood cells prevents relapses in a mouse model of relapsing-remitting multiple sclerosis. J Transl Med 14:99. doi:10.1186/s12967-0160860-6

89. Harrison LC, Hafler DA (2000) Antigen-specific therapy for autoimmune disease. Curr Opin Immunol 12:704-711. doi:10.1016/S0952-7915(00)00166-7 
90. Torres-Aguilar H, Blank M, Jara LJ, Shoenfeld Y (2010) Tolerogenic dendritic cells in autoimmune diseases: crucial players in induction and prevention of autoimmunity. Autoimmun Rev 10:8-17. doi:10.1016/j.autrev.2010.07.015

91. Hackstein H, Thomson AW (2004) Dendritic cells: emerging pharmacological targets of immunosuppressive drugs. Nat Rev Immunol 4:24-34. doi:10.1038/nri1256

92. Adorini L, Giarratana N, Penna G (2004) Pharmacological induction of tolerogenic dendritic cells and regulatory T cells. Semin Immunol 16:127-134. doi:10.1016/j.smim.2003.12.008

93. Chiuso-Minicucci F, Ishikawa LL, Mimura LA, Fraga-Silva TF, França TG, Zorzella-Pezavento SF, Marques C, Ikoma MR, Sartori A (2015) Treatment with vitamin D/MOG association suppresses experimental autoimmune encephalomyelitis. PLoS One 10:e0125836. doi:10.1371/journal.pone.0125836

94. Ishikawa LLW, Colavite PM, da Rosa LC, Balbino B, França TG, Zorzella-Pezavento SF, Chiuso-Minicucci F, Sartori A (2014) Commercial bovine proteoglycan is highly arthritogenic and can be used as an alternative antigen source for PGIA model. Biomed Res Int 2014:148594. doi:10.1155/2014/148594

95. Muehleisen B, Gallo RL (2013) Vitamin D in allergic disease: shedding light on a complex problem. J Allergy Clin Immunol 131:324-329. doi:10.1016/j.jaci.2012.12.1562

96. Cantorna MT, Hayes CE, DeLuca HF (1998) 1,25Dihydroxycholecalciferol inhibits the progression of arthritis in murine models of human arthritis. J Nutr 128:68-72

97. Haga HJ (2013) Vitamin D in rheumatoid arthritis. Expert Rev Clin Immunol 9:591-593. doi:10.1586/1744666X.2013.811177

98. Pedersen AW, Claesson MH, Zocca MB (2011) Dendritic cells modified by vitamin D: future immunotherapy for autoimmune diseases. Vitam Horm 86:63-82. doi:10.1016/B978-0-12-3869609.00003-4

99. Albert ML, Jegathesan M, Darnell RB (2001) Dendritic cell maturation is required for the cross-tolerization of $\mathrm{CD} 8+\mathrm{T}$ cells. Nat Immunol 2:1010-1017. doi:10.1038/ni722

100. Menges M, Rössner S, Voigtländer C, Schindler H, Kukutsch NA, Bogdan C, Erb K, Schuler G, Lutz MB (2002) Repetitive injections of dendritic cells matured with tumor necrosis factor alpha induce antigen-specific protection of mice from autoimmunity. $\mathrm{J}$ Exp Med 195:15-21. doi:10.1084/jem.20011341

101. Parungo CP, Soybel DI, Colson YL, Kim SW, Ohnishi S, DeGrand AM, Laurence RG, Soltesz EG, Chen FY, Cohn LH, Bawendi MG, Frangioni JV (2007) Lymphatic drainage of the peritoneal space: a pattern dependent on bowel lymphatics. Ann Surg Oncol 14:286-298. doi:10.1245/s10434-006-9044-6

102. Jeffery LE, Wood AM, Qureshi OS, Hou TZ, Gardner D, Briggs Z, Kaur S, Raza K, Sansom DM (2012) Availability of 25hydroxyvitamin $\mathrm{D}(3)$ to APCs controls the balance between regulatory and inflammatory T cell responses. J Immunol 189:51555164. doi:10.4049/jimmunol.1200786

103. Farias AS, Spagnol GS, Bordeaux-Rego P, Oliveira CO, Fontana AG, de Paula RF, Santos MP, Pradella F, Moraes AS, Oliveira EC, Longhini AL, Rezende AC, Vaisberg MW, Santos LM (2013) Vitamin D3 induces IDO+ tolerogenic DCs and enhances Treg, reducing the severity of EAE. CNS Neurosci Ther 19:269-277. doi:10.1111/cns.12071

104. Han GM, O'Neil-Andersen NJ, Zurier RB, Lawrence DA (2008) $\mathrm{CD} 4+\mathrm{CD} 25$ high $\mathrm{T}$ cell numbers are enriched in the peripheral blood of patients with rheumatoid arthritis. Cell Immunol 253: 92-101. doi:10.1016/j.cellimm.2008.05.007

105. Agrawal T, Gupta GK, Agrawal DK (2013) Vitamin D supplementation reduces airway hyper-responsiveness and allergic airway inflammation in a murine model. Clin Exp Allergy 43:672683. doi:10.1111/cea.12102

106. He CS, Handzlik M, Fraser WD, Muhamad A, Preston H, Richardson A, Gleeson M (2013) Influence of vitamin D status on respiratory infection incidence and immune function during 4 months of winter training in endurance sport athletes. Exerc Immunol Rev 19:86-101

107. Czifra G, Tóth B, Kovács I, Bíró T, Griger Z, Baráth S, Tarr T, Zeher M, Sipka S (2014) The in vitro treatment with vitamin D3 is ineffective on the expression of PKC isoenzymes, but decreases further the impaired production of IL-2 in the T lymphocytes of SLE patients. Rheumatol Int 34:717-720. doi:10.1007/s00296-013-2751-y

108. Villaggio B, Soldano S, Cutolo M (2012) 1,25-Dihydroxyvitamin D3 downregulates aromatase expression and inflammatory cytokines in human macrophages. Clin Exp Rheumatol 30:934-938

109. Bemiss CJ, Mahon BD, Henry A, Weaver V, Cantorna MT (2002) Interleukin-2 is one of the targets of 1,25-dihydroxyvitamin D3 in the immune system. Arch Biochem Biophys 402:249-254. doi:10.1016/S0003-9861(02)00082-6

110. Niino M, Fukazawa T, Miyazaki Y, Takahashi E, Minami N, Amino I, Fujiki N, Doi S, Kikuchi S (2014) Suppression of IL10 production by calcitriol in patients with multiple sclerosis. $\mathrm{J}$ Neuroimmunol 270:86-94. doi:10.1016/j.jneuroim.2014.03.011

111. Matilainen JM, Husso T, Toropainen S, Seuter S, Turunen MP, Gynther P, Ylä-Herttuala S, Carlberg C, Väisänen S (2010) Primary effect of $1 \alpha, 25(\mathrm{OH}) 2 \mathrm{D} 3$ on IL-10 expression in monocytes is short-term down-regulation. Biochim Biophys Acta 1803: 1276-1286. doi:10.1016/j.bbamcr.2010.07.009

112. Moghaddami M, Mayrhofer G, Anderson PH, Morris HA, Van Der Hoek M, Cleland LG (2012) Efficacy and mechanisms of action of vitamin D in experimental polyarthritis. Immunol Cell Biol 90:168-177. doi:10.1038/icb.2011.22

113. Bansal AS, Henriquez F, Sumar N, Patel S (2012) T helper cell subsets in arthritis and the benefits of immunomodulation by 1 , $25(\mathrm{OH})_{2}$ vitamin D. Rheumatol Int 32:845-852. doi: $10.1007 /$ s00296-011-2077-6

114. Kang Y, Xu L, Wang B, Chen A, Zheng G (2008) Cutting edge: immunosuppressant as adjuvant for tolerogenic immunization. $\mathrm{J}$ Immunol 180:5172-5176. doi:10.4049/jimmunol.180.8.5172

115. Kang Y, Zhao J, Liu Y, Chen A, Zheng G, Yu Y, Mi J, Zou Q, Wang B (2009) FK506 as an adjuvant of tolerogenic DNA vaccination for the prevention of experimental autoimmune encephalomyelitis. J Gene Med 11:1064-1070. doi:10.1002/jgm.1387

116. Mannie MD, Abbott DJ, Blanchfield JL (2009) Experimental autoimmune encephalomyelitis in Lewis rats: IFN-beta acts as a tolerogenic adjuvant for induction of neuroantigen-dependent tolerance. J Immunol 182:5331-5341. doi:10.4049/jimmunol.0803756

117. Colmegna I, Ohata BR, Menard HA (2012) Current understanding of rheumatoid arthritis therapy. Clin Pharmacol Ther 91:607-620. doi:10.1038/clpt.2011.325

118. Uysal H, Nandakumar KS, Kessel C, Haag S, Carlsen S, Burkhardt H, Holmdahl R (2010) Antibodies to citrullinated proteins: molecular interactions and arthritogenicity. Immunol Rev 233:9-33. doi:10.1111/j.0105-2896.2009.00853.x

119. Song YW, Kang EH (2010) Autoantibodies in rheumatoid arthritis: rheumatoid factors and anti-citrullinated protein antibodies. QJM 103:139-46. doi:10.1093/qjmed/hcp165

120. Bläss S, Engel JM, Burmester GR (2001) The immunologic homunculus in rheumatoid arthritis. A new viewpoint of immunopathogenesis in rheumatoid arthritis and therapeutic consequences. Z Rheumato 60:1-16. doi:10.1007/s003930170093

121. Penna G, Adorini L (2000) 1 Alpha,25-dihydroxyvitamin D3 inhibits differentiation, maturation, activation, and survival of dendritic cells leading to impaired alloreactive $\mathrm{T}$ cell activation. $\mathrm{J}$ Immunol 164:2405-2411. doi:10.4049/jimmunol.164.5.2405

122. Chen S, Sims GP, Chen XX, Gu YY, Chen S, Lipsky PE (2007) Modulatory effects of 1,25-dihydroxyvitamin D3 on human B cell differentiation. J Immunol 179:1634-1647. doi:10.4049/jimmunol.179.3.1634 
123. Heine G, Niesner U, Chang HD, Steinmeyer A, Zügel U, Zuberbier T, Radbruch A, Worm M (2008) 1,25Dihydroxyvitamin $\mathrm{D}(3)$ promotes IL-10 production in human $\mathrm{B}$ cells. Eur J Immunol 38:2210-2218. doi:10.1002/eji.200838216

124. Colin EM, Asmawidjaja PS, van Hamburg JP, Mus AM, van Driel M, Hazes JM, van Leeuwen JP, Lubberts E (2010) 1,25Dihydroxyvitamin D3 modulates Th17 polarization and interleukin-22 expression by memory $\mathrm{T}$ cells from patients with early rheumatoid arthritis. Arthritis Rheum 62:132-142. doi:10.1002/art.25043

125. Jeffery LE, Qureshi OS, Gardner D, Hou TZ, Briggs Z, Soskic B, Baker J, Raza K, Sansom DM (2015) Vitamin D antagonizes the suppressive effect of inflammatory cytokines on CTLA-4 expression and regulatory function. PLoS One 10:e0131539. doi:10.1371/journal.pone.0131539

126. Laragione T, Shah A, Gulko PS (2012) The vitamin D receptor regulates rheumatoid arthritis synovial fibroblast invasion and morphology. Mol Med 18:194-200. doi:10.2119/molmed.2011.00410

127. Feng X, Lv C, Wang F, Gan K, Zhang M, Tan W (2013) Modulatory effect of 1,25-dihydroxyvitamin D3 on IL1 $\beta$ induced RANKL, OPG, TNF $\alpha$, and IL-6 expression in human rheumatoid synoviocyte MH7A. Clin Dev Immunol 2013: 160123. doi:10.1155/2013/160123

128. Tetlow LC, Woolley DE (1999) The effects of 1 alpha,25dihydroxyvitamin $\mathrm{D}(3)$ on matrix metalloproteinase and prostaglandin $\mathrm{E}(2)$ production by cells of the rheumatoid lesion. Arthritis Res 1:63-70. doi:10.1186/ar12

129. Kim TH, Lee B, Kwon E, Choi CH, Sung IH, Kim Y, Sohn J, Ji JD (2013) 1,25-Dihydroxyvitamin D3 inhibits directly human osteoclastogenesis by down-regulation of the c-Fms and RANK expression. Joint Bone Spine 80:307-314. doi:10.1016/j.jbspin.2012.09.011 